\title{
In Search of a House with a View: The conception of dwelling in E.M. Forster's Howards End and Iris Murdoch's The Sea, The Sea
}

\author{
Tereza Topolovská \\ Faculty of Education, Charles University in Prague, Celetná 13, 11000 Praha 1, Czech Republic \\ E-mail: tereza.topolovska@pedf.cuni.cz
}

Received: 07-03-2016

Published: 01-07-2016
Accepted: 12-05-2016

doi:10.7575/aiac.ijalel.v.5n.4p.189
Advance Access Published: May 2016

URL: http://dx.doi.org/10.7575/aiac.ijalel.v.5n.4p.189

\begin{abstract}
This article elaborates on the thematic connections between E.M. Forster's 1910 Howards End and Iris Murdoch's 1978 The Sea, The Sea, namely their poetic conception of dwelling. Besides echoing the major social and cultural concerns of their individual periods, these novels vigorously examine timeless issues as the nature of dwelling, the extent of the influence of a social class on the treatment of environmental issues. Both novels mirror the wide-ranging and longstanding debate that engages with diverse variables of the equation comprising technological progress, undisturbed nature and intensity of human involvement. The great variety of subject matter in both novels might easily have resulted in a melange of pompous moralising had they not featured two houses, namely Howards End and Shruff End, whose symbolism anchors the narration while adding to the thematic richness of both works. Operating both on metaphorical and literal levels, the houses in question provide a solid foundation for the analysis of the texts.
\end{abstract}

Keywords: dwelling, E.M. Forster, Iris Murdoch, poetics of space

\section{Introduction: "Houses are alive. No?" Houses from the Viewpoint of Modernist Sensibility}

"It's the houses that are mesmerising me, I've no control over the saucy things. Houses are alive. No?" (Forster, HE 132)

Twentieth-century British fiction contributed to the discussion of the role of houses in literature by its insistence on their personified character (Note 1), observable in particular in the works of Modernists ${ }^{\text {(Note } 2)}$ such as Virginia Woolf, Vita Sackville-West or Elizabeth Bowen. The house E.M. Forster presents in Howards End opens a new chapter in the understanding of the roles houses may assume. Bearing a striking resemblance to the Hertfordshire residence where the author and his mother spent ten years, Howards End anchors his vision of England and the world. Forster's narration features a continuous calling for connection. Life in a spiritual continuum is opposed to an emerging civilization of flux, of constant erratic movements typical of a culture in which internal existence has been replaced by external accumulation.

In Howards End Forster establishes a basic dichotomy in the opposition of the Schlegel sisters, namely Margaret and Helen, and the Wilcox family. He later labelled the two groups they represent "Mollycoddles" (the Schlegels) and "Red-bloods" (the Wilcoxes) in his unfinished novel Arctic Summer. This elemental dualistic principle is slightly disrupted by Ruth Wilcox and her "sanctuary", Howards End, and by the Schlegels' all-comprising, and at times brutal and self-absorbed, principle of connection. Where one would expect a simple animosity between the two clans, the two households, Forster places adversaries at the very centre of the opposing side, be it Ruth Wilcox, the wife of Henry Wilcox, or, later, Margaret Schlegel connecting the two opposite poles through her own exogamic marriage to Henry Wilcox.

Iris Murdoch's The Sea, The Sea, revolves around the self-inflicted, hermit-like existence of Charles Arrowby, a formerly famous stage director, whose decision to become "good" entails his retreat to a secluded seaside villa, entitled fittingly "Shruff End", on the north coast of England. Documenting his struggles in a fictitious "memoir/diary/philosophical journal", he is forced to abandon his meditation, as he is immediately immersed into an emotional tumult caused by the unexpected appearance of his former lovers and other visitors. His failed attempts at transforming himself into an authentic, good person, without any external intrusions, show the humanist preoccupation of Murdoch and serve as an inexhaustible source of comedy.

Both novels display a cyclical thematic composition which is highlighted by the chronological and spatial positioning of the plot as well as the employment of prevalently circular imagery (Note 3). Failed attempts at solving the existential struggle that verge on comedy, the ominous undertone of impending ecological disaster threatening the unspoilt view in both literal and metaphorical senses, and the degree and consequences of human involvement in nature, are all points of reference strengthening the thematic connections between Murdoch's The Sea, the Sea and Forster's Howards End. Howards End and Shruff End, the fictional houses at the centre of the novels, anchor the narration while incarnating a 
number of functions and meanings: they are emblems of the social classes to which their owners belong, they are attributed with highly humanised traits such as an eagerness to express their will, becoming slightly treacherous and ghastly in the process, they are spiritual sanctuaries reviving a sense of space in their owners, and they symbolise their owners' connection with the land. Thus they provide their uprooted inhabitants with a sense of belonging to the world.

\section{Staging a retreat: Theatrical attempts at dwelling}

"Now I shall abjure magic and become a hermit: put myself in a situation where I can honestly say that I have nothing else to do but to learn to be good." (Murdoch 2)

One of the main allures of temporary or permanent ownership of a country house is seclusion, with all its desirable implications, such as an uncorrupted view, uninterrupted solitude, retreat, spiritual and physical awakening or renewal, and finding long-lost connections in all possible senses. Time and its habitual requirements and restraints seem suspended in the country: "I'm only saying. How does it happen that Thursday seems like Friday? We're out of the city. We're off the calendar. Friday shouldn't have an identity here." (DeLillo 19) Indeed, it is the cyclical movements of the sea or seasons which replace the arbitrary division of time into hours, weeks and months.

Such a type of secluded, privileged existence has always inspired literary creation. From John Banville to Françoise Sagan or Keri Hulme, it seems that cloistered within the walls of houses situated on the sea coast, creative potential blossoms and artists are eager to translate their experience into fictional narrative. Lauren, the grieving widow and body artist in The Body Artist, a novel by American author Don DeLillo set in a secluded house on the New England coast, at first relishes the separation which nourishes the artistic performance into which she translates her grief but, gradually, she feels stifled and needs to free herself: "She walked into the room and went to the window. She opened it. She threw the window open. She didn't know why she did this. Then she knew. She wanted to feel the sea tang on her face and the flow of time in her body, to tell her who she was" (DeLillo 132).

Similarly, Charles Arrowby is eager to translate his hermit's existence into artistic form at the beginning of his stay by the sea. He has two major sources of inspiration and thus two major themes he is willing to portray - himself and the sea: "The sea. I could fill a volume simply with my word-pictures of it" (Murdoch 2). Charles's spiritual and ethical struggle is projected into the form of the novel, which is endowed with a great degree of intertextuality; the affinity to William Shakespeare's The Tempest is manifested by his close resemblance to another great stage director, Prospero, and an excessive employment of sea imagery. As a man of the world and as an artist, Charles feels entitled to stage the drama of his new existence as well as to accompany it with lengthy remarks concerning the nature of the theatre, the novel and the viability of their connection with the "real world". Theatre, even at its utmost best, is portrayed as being profoundly scurrilous: "[...] the theatre, even at its most 'realistic', is connected with the level at which, and the methods by which, we tell our everyday lies" (Murdoch 36). Its lying nature is ascribed to the fact that emotions either rule a personality or play an inconsequential part in its determination, and therefore mediocre feelings and ideas, those we express everyday and those we perceive in others, are acted and that is why "all the world is a stage, and why the theatre is always popular and indeed why it exists: why it is like life, and it is like life even though it is also the most vulgar and outrageously factitious of all the arts" (Murdoch 36). Though the novel cannot boast the same degree of spectacularity as the theatre, it is, nevertheless, much closer to truth and is therefore chosen to reflect Charles's preoccupation: to be humble, to live well, to slow down, to replace the chaos of London with the stillness of the countryside with its routines and the circularity of its seasonal existence.

The proximity of natural elements, which is often achieved at great expense, both financial and in terms of sacrificing basic modern residential comforts, such as electricity, plumbing, and efficient heating systems, forces the human being to fully embrace the notion of living in a present that cannot be controlled by any sort of plan or design. Thus, life may seem to be comic or dreadful but it never acquires the quality of tragedy since tragedy, with its artificial pomp and grandeur, "belongs to the cunning of the stage" (Murdoch 39). Theatre is thus marked, and ironically so by a former stage director, as facetious. And although Charles plans to spend his time swimming, eating, and, last but not least, reading his books, and Shakespeare in particular, his stay by the sea involves almost none of his intended activities and is filled with unexpected visitors and emotional turmoil, to the point that the whole plot resembles a badly staged melodrama.

Howards End lacks the theatrical preoccupation of The Sea, The Sea, but its overall form has often been compared to that of "a morality play" (Stone, "Howards End: Red-bloods and Mollycoddles." 255) in which the dichotomy between the Red-bloods and the Mollycoddles acquires an almost allegorical dimension. The close proximity of life and drama, their constant shifting, mingling and interchanging, may be delineated as one of the major motifs of The Sea, The Sea. Howards End may be seen as echoing, if less explicitly, this belief in a close connection between life and drama: "I inflict all this on you because once you said that life is sometimes life and sometimes only a drama, and one must learn to distinguish tother from which, and up to now I have always put that down as 'Meg's clever nonsense.' But this morning, it really does seem not life but a play" (Forster, $H E$ 4). What is more, the Schlegels feel a strong artistic inclination which manifests itself in their efforts "to connect" and thus to commune with the world and mediate this communion to others. Shruff End and Howards End thus anchor the narration, enable the staging of the dramatic events, provide necessary inspiration, shelter their owners in their artistic endeavours and symbolise their visions of the world and authentic existence. 


\section{Threatening the rural pastoral}

When E.M. Forster inveighed against the suburban villas gobbling up the countryside (Note 4), he opposed the irritating nature of so-called "Metro-land" which heavily promoted a set of commonly held beliefs in the beneficial effect of life in the countryside. This building of suburbs on surplus railway land in the early twentieth century promoted the idea that the spiritual growth and the physical well-being of an individual were conditioned by proximity to nature. Obviously, the past was romanticised as a period which enabled such a kind of life, which was reflected in the deliberately pre-modern design of the new houses. Nevertheless, the major motivation for the development of Metroland was largely economic. The Metropolitan Railway saw an opportunity and, by supplying the means of connection, enabled a massive expansion of London into the countryside, which defined a new style of living - the suburb. Its essence was that "it would provide the benefits of country living with the convenience of being close to the city, so that a man [...] could travel by train to work in the noise and grime of the city but come home in the evening to his family and the healthy air of the countryside" (Dimbleby 233).

The growing masses of commuters and spreading suburbs horrified Forster as they threatened to obstruct the view, robbing him of "the sense of space, which is the basis of all earthly beauty" (Forster, HE 174). To yearn for an unspoilt view and empty spaces in a world becoming more and more densely crowded every day is a mark of the reclusive behaviour so typical for Georgian admirers of the countryside. Its observers, such as Forster, came searching for its soothing atmosphere. Like so many of his contemporaries he felt tired, haunted and daunted by the strain of citified life and was inclined to contemplate the country as "a version of rural history[...]The honest past, the pagan spirit" (Williams, p. 256). Thus, long-term residents of the countryside were ignored, silenced or viewed through the reductive lens of a pastoral vision. "The Georgian version used rural England as an image for its own internal feelings and ideals" (Williams 258). What is more, Forster and others situated their visions in those parts of England that were spared the effects of industrialisation, most frequently in the shires or the south of the country. This pastoral envisioning sets its roots firmly into the soil of the ancient, unspoilt land and thus connects its inhabitants with the past. Seen from this perspective, Forster's depiction of the Schlegel sisters' quest for home may be viewed as "a search of the kind of dwelling that could symbolize or even embody uncorrupted Englishness" (Lucas 62). And it is by means of connection, of putting down roots, that the existence of England is revived: "She recaptured the sense of space, [...], and, starting from Howards End, she attempted to realize England" (Forster, HE 174).

There is a motif which emphasises the association with roots and that is the presence of ancient trees. In the case of Howards End, it is "the finest wych-elm in Hertfordshire": "the place (Howards End) was English, and the wych-elm that she saw from the window was an English tree. No report had prepared her for its peculiar glory" (Forster, $H E$ 176). Forster even stresses the universal "binding force" (Forster, HE 222) a tree is able to exercise on the character and warns against the perils of cosmopolitanism, which he sees as loosening the ties with the earth, the countryside and consequently with a sense of belonging, geographically as well as spiritually: "Under cosmopolitanism, if it comes, we shall receive no help from the earth. Trees and meadows and mountains will only be a spectacle, and the binding force they once exercised on character must be entrusted to Love alone. May Love be equal to the task!" (Forster, HE 176). There is yet another Modernist work in which a tree is given a prominent place, symbolising the firm link between the present and the past: the Great Tree of Groby whose cutting down is the last of all the imaginable blows and humiliations Christopher Tietjens is willing to endure from his wife, Sylvia, in Ford Madox Ford's opus magnum, Parade's End (1924-1928). The countryside, at least from the point of view of Edwardian, Georgian and Modernist fiction (Note 5), is associated firmly with the past, with roots, with Englishness, while people in the cities, all the crowds of hurrying, uprooted individuals, are portrayed as desperately failing to establish or even seek connection.

Natural imagery is assigned a prominent place in both Forster's and Murdoch's works, although it does not play the principal part in the narration. It extends well beyond the motifs of trees (Howards End) and rocks (The Sea, The Sea) into the realm of nature, and more specifically, the sea. The fascination of the sea is, besides its unique aesthetic properties, caused by its ambiguous nature, which unites cyclical, periodical, predictable movements with vastness and caprice. Murdoch's The Sea, The Sea pays homage to this unique phenomenon since it is the sea alone which, though unpredictable and cruel, retains its ethereal beauty and grandeur from the opening lines until the end. Notwithstanding Howards End's position inland, Forster contrasts the richness of the sea and its unfailing nature with the flux of London which reflects the panta rhei motions of rivers: "II hate this continual flux of London. It is an epitome of us at our worst - eternal formlessness; all the qualities, good, bad, and an indifferent, streaming away - streaming, streaming forever. That's why I dread it so. I mistrust rivers, even in scenery. Now, the sea-"' (Forster, HE 156). In his collection of essays, Two Cheers for Democracy, published in 1951, Forster saw the long-standing, unshakeable position of the sea and its artistic and poetic potential threatened by the ecological and political perils the twentieth century inflicted upon it:

Yet the sea today certainly is in retreat. Occasionally it reasserts itself, as in the Kontiki expedition, and occasionally, through the fringe of oil and dead birds and the chonking and bobbing of metal objects, we catch a glimpse of it from the shore. But it is in retreat poetically. A poet is needed to arrest it, to restore Neptune his majesty, to wet Canute his fears, to float the Old Man in the Boat. (Forster, Two Cheers for Democracy 271)

The pastoral, as depicted in both The Sea, The Sea and in Howards End, is never a fully-fledged one, it is presented as a temporary equilibrium and is highly prone to corruption. Neither the trees nor the meadows nor the sea are spared the possible risks emerging from human involvement in the countryside. The effort to recapture a sense of space and, 
consequently, the land and the nation, is characterised as fruitless and corrupting if performed on a larger scale than by a few selected individuals and may be therefore labelled a highly exclusive activity.

\section{Houses and class}

“"Then she shocked me. She went up to the fireplace where the wild duck were, there were three hung up, thirty-bob each and before you could say Jack Knife she had them off the hooks and bang crash on the hearth. In smithereens.

Thank you very much, I said, very sarcastic.

“"A house as old as this has a soul. And you can't do things like that to beautiful things like this old, old room so many people have lived in. Can't you feel that?"” (Fowles 54)

Both Howards End, which is the result of the refurbishment of an old farm, and Shruff End, which is a typical seaside villa, are repeatedly described as country houses, both by the authors of the novels as well as scholarly works on the subject. Nevertheless, they incarnate a specific vision originating in the myth of the country house and it is exactly this discrepancy and the subsequent tension between lavish, idealised palaces and their far more common counterparts such as villas, cottages and farms, which energises both works. "Howards End is not a great country house. It is scaled down to a far more modest size than those houses that had been celebrated by Jonson, Carew, Marvell, Pope and others; but its naturalness echoes theirs, the implication that it was built with no man's ruin, no man's groan" (Lucas 69). Neither is Shruff End a secluded aristocratic seat, both are rather ordinary middle-class houses. Since Howards End is dominated by the question of class and, according to Daniel Born, it provides "the most comprehensive picture of liberal guilt in this century" touching with striking precision: "the sensitive spot in the consciousness, or conscience, of the liberal literary intelligentsia" (Forster, $H E$, Introduction, p. 8 -9), the scale of the house in question provides the narration with a greater innovativeness than in the case of an upscale town or country house.

Although the precise place on the social ladder may differ slightly since the Schlegels' fortune probably surmounts that of Charles, both Forster and Murdoch create universes which are decisively middle-class. As Malcolm Bradbury points out, Murdoch peopled her novels with a number of middle-class prototypes: "Though the forms were various, there was indeed something called Murdochland, as distinctive as Greeneland" (Bradbury 370). Although her novelistic legacy is sometimes considered to be overblown and her novels peopled with numerous, seemingly flat characters, burdened with over-crafted plots, abounding with references to the self-reflective properties of the novel, it is necessary to underline that her fiction is always merged with her philosophic preoccupations. Having filled her novels with peculiar characters entangled in philosophical nets, religious beliefs or spiritual enchantments, Murdoch forces these characters to deal with the fundamental questions human beings face. In this way Murdoch's novels replicate the failures and imperfections of human existence in the realm of fiction through what may be regarded as structural flaws. Pushing her readers to the extreme of fictionality, her literary efforts acquire the position of "wise encounters with the density of experience and otherness", urging their readers to: "return to contact with the real" (Bradbury 372).

From the point of view of subject matter, Howards End represented an extreme expansion for Forster: "Its thematic problems arise in part because Forster tried to say and do too much. 'I think Howards End is all right,' he wrote on his eightieth birthday. 'But I sometimes get a little bored with it. There seems too much, too many social nuances, there", (Stone "Howards End: Red-bloods and Mollycoddles." 267) (Note 6) Unlike his previous novels, concerned predominantly with the purely private concerns of individual characters, Howards End focuses on the representatives of England's main economic power - the middle classes. With this rich and inspiring ground to build upon, he continues his construction by means of joining, clashing and mingling contradictory elements such as: the country and the city, the rich and the poor, the intellectual liberalism of the Schlegel sisters and the crude materialism of the Wilcoxes, the feminine and the masculine. In the very way in which the English countryside (in its mystical, idealized sense) clashes with "the hollow Suburbia" (Forster, HE 13), the country opposes the city, meadows and forests defy motor-cars, and anchored, authentic existence counters the flux of civilisation with its hurrying men.

Howards End puts the possibility of the connection of these adversaries to the test. Margaret Schlegel's motto, "Only connect!" reverberates throughout the novel as her striving for connection acquires an almost heroic dimension and brings fatal consequences to most of those with whom she, or her sister Helen, tries to connect. The wide social scope of the novel enables the inclusion of Leonard Bast, an aspiring representative of a lower class, who is trying to reach the heights of the middle class, at least through his clumsy attempts to embrace a cultured life. Forster himself undermines the plausibility of this inclusion stating: "We are not concerned with the very poor. They are unthinkable, and only to be approached by the statistician or the poet. This story deals with gentlefolk, or with those who are obliged to pretend that they are gentlefolk" (Forster, HE 38). Leonard's ambition to achieve an intellectual existence is continually ridiculed: "Oh, it was no good, this continual aspiration. Some are born cultured; the rest had better go in for whatever comes easy. To see life steadily and to see it whole was not for the likes of him" (Forster, HE 47) and it is only through his connection with Helen that something fruitful is produced. It is a child, the inheritor of Howards End, whose origin may be seen as an attempt to reconcile or "connect" the two distant, if not opposing sides. Nevertheless, the disruptive potential of those connections proposed, or even extorted, by the Schlegel sisters is projected into the overall structural composition of the novel, which follows Margaret's dictum and twists the plot into a cyclical shape. 
4.1 An exclusive pastoral and the perils of middle-class Arcadia

"To love space is to wish people elsewhere - and if there is nowhere else to go?" (Stone, "Howards End: Red-bloods and Mollycoddles." 179)

Forster's Howards End, besides other topics, vigorously examines the power and significance of money and its role in social stratification. Forster, along with other authors, reflected ethical concerns regarding the financial manipulation that had established England as the world's leading financial power: "Money acquired by manipulation rather than by manual labour inaugurated a morality so much larger and more exciting than a pitch-beck calculus of right and wrong that writers found themselves in possession of a new and vital theme" (Stone "Howards End: Red-bloods and Mollycoddles." 250). The Schlegel sisters, the Cazalets, Miranda Grey and Charles Arrowby are all people who, at least formally, could be described as upper-middle-class, entitled to a pastoral life in the countryside, or at least possessing the possibility of choice between the country and the city. However, authors such as Forster and John Fowles also create powerful portrayals of representatives of lower classes, such as Leonard Bast or Frederick Clegg, who are deprived of "essential experience of nature and its beauty, which is so important for developing a sense of humanity" (Chalupský 18).

Seen from this perspective, both Howards End and The Sea, The Sea, or even The Collector, which depict the experience of typical urban dwellers with life in the countryside, associate culture, cultivation, sensitivity to nature and consequent aspiration to environmentalism almost exclusively with the middle classes. What is more, the country, in the ideal case, should only be sparsely populated in order to be tolerable. British fiction has provided a broad variety of responses, ranging from exclusive to inclusive approaches, with regard to the disturbance of the landscape by the presence of other people. Where Forster offers the house with a view achieved at the expense of sacrifices of different types in Howards End, Murdoch shows a solitude overrun with unwanted visitors in The Sea, the Sea and Ian McEwan, in his 1998 novel, Amsterdam, presents a cautionary tale about what a deliberate ignoring of a possible crime scene, which threatened to disrupt the desired peaceful view of nature, may inflict.

In the summer of 2013 , the debate over the exclusivity of the countryside in terms of population and class spurred a series of wide-ranging articles on the website of The Guardian newspaper. George Monbiot, an environmental writer and an ecological activist, declared his sincere love of nature and "nature writing" whereas journalist Steven Poole immediately described this love of nature as a form of "bourgeois escapism" (Note 7). Where Monbiot argues for "rewilding", Poole remarks:

The idealisation of the natural world is as old as the city, to the corrupting influence of which a return to pastoral life is always presented as a cure. But the increasing modern appetite of metropolitan readers for books about walking around and discovering yourself in nature is the literary equivalent of the rise of the north London "farmers' market". Both feed on nostalgie de la boue - the French term for a kind of rustic-fancying inverted snobbery, which literally means 'nostalgia for the mud' (Poole, "Is our love of nature writing bourgeois escapism?").

Having scrutinized a vast amount of contemporary nature writing, Poole expresses the fundamental paradox of all writing about nature, echoed in Forster's Howards End, Murdoch's The Sea, The Sea, and McEwan's Amsterdam: "Paradise, it seems, has no people in it." (Poole, "Is our love of nature writing bourgeois escapism?") (Note 8). Deep interest in questions concerning the conflicting views concerning the inclusion vs. exclusion of human involvement in nature, which echoes the Romantic preoccupation with its solitary experience, is thus still clearly present in the sphere of mass culture, namely journalism, in Britain, indicating a persisting concern with the class and exclusivity connotations of country living.

The year 1978, which saw the publishing of The Sea, the Sea, also saw the publication of Fay Weldon's "Weekend". In her short story, Weldon echoed Murdoch's preoccupations and pertinently responded to the growing popularity in the period of country-life aspirations by playfully underlining the paradoxical nature of a weekend spent in a cottage in the countryside. A supposedly idyllic gathering of family and friends is seen from the point of view of a housewife who, tired after a gruelling week juggling office work and the demands of her family, continues her struggle with renewed intensity during a "relaxing" weekend, slaving over the stove in an ill-equipped kitchen, washing copious amounts of dishes and waiting on guests who keep urging her to relax. The shortage of supplies, inadequacy of the kitchen equipment, the demands of her family members and their insistence that her feverish activity is spoiling the relaxing nature of the weekend, further highlight the paradoxical and inauthentic nature of the middle-class aspiration to the pastoral. Weekly country-house commuting is depicted as a contribution to the set of burdens a middle-class woman has to endure (Note 9).

The majority of fictional country houses are often depicted as inconvenient, high-maintenance and, at times, even treacherous places. Their impracticality often resides in the fact that they were designed for a different function in a different period and are therefore unable to fulfil satisfactorily the practical demands of modern inhabitants. The weathered charm of the places is put to the test when the new inhabitants are forced to deal with a lacking or inadequate plumbing system, smoking fireplaces, huge rooms which are impossible to heat properly, a vast number of charming, but inhabitable rooms, and masses of bric-a-brac accumulated over the centuries.

Charles Arrowby, the main character of Murdoch's novel The Sea, The Sea, intends to detach himself from the corrupting forces of the urban milieu. He hopes to achieve a spiritual cleansing and awakening provoked by a self- 
inflicted isolation in a seaside villa, Shruff End, which is, despite its unwelcoming, dreary character, advertised as a charming place: "The agent, smiling could see I loved the place and the disadvantages meant nothing. 'It is unique, sir,' he said. Yes it is" (Murdoch 11). Reasonable demands for comfort, suitability and practicality are overshadowed by the house's 'uniqueness' and potential to become a perfect hermit's den, transforming its inhabitant into an enlightened creature elevated above everyday material concerns. Nevertheless, after numerous attempts it turns out that Shruff End does not accommodate to Charles, nor does Charles accommodate to the house. It repeatedly manifests its own will and its hallucinatory properties gradually erode the clear distinction between reality and fantasy, vision and dream. With its repeated visions of the sea monster, occasional ghosts, and objects falling from shelves and tables for no reason, The $\mathrm{Sea}$, The Sea embraces elements typical for the Gothic novel, which adds yet another layer of interpretation to this ironic revisiting of the narrative of spiritual awakening in the realm of the unspoilt countryside.

\section{Athletes and appliances: Tragic in/ability to connect}

When Charles retires from the glamorous London life of a famous stage director, he chooses the concept of "simple but sumptuous" in terms of his life, a concept which had previously characterised his culinary efforts, fittingly described by a journalist in the novel as "Wind in the Willows food": "What is more delicious than fresh hot buttered toast, with or without the addition of bloater paste? Or plain boiled onions with a little corned beef if desired? And well-made porridge with brown sugar and cream is a dish fit for a king" (Murdoch 9 -10). The meals Charles prepares play a crucial role in the process of consolidating the overall poetics of the work as they incarnate Charles's ostentatious preoccupation with "intelligent hedonism" and "felicitious gastronomic intelligence" (Murdoch 9).

Charles deprives himself voluntarily of electricity, hot water, heating and sophisticated shopping facilities. All such luxuries, gimmicks, gadgets and appliances are associated with the corrupted life of citified existence. Charles wants to live a life of simple, if even more sophisticated, pleasures, such as contemplating the colour of the skies and the sea, filling his notebook with their images: "The sea. I could fill a volume simply with my word-pictures of it" (Murdoch 2). In the beginning, he intends to divide his time between walking, cooking, resting, reading and, most importantly, swimming: "I swam about quietly, looking at that special 'swimmer's view' of the sea, and feeling, for the time possessing and possessed" (Murdoch 150).

Nevertheless, the elements he meant to admire and indulge in, reject, torture, mock and haunt him. The house is unbearably uncomfortable and creepy, probably even haunted. The neighbours and weather are hostile. What is more, it is almost impossible to go swimming because the cliffs by the house do not enable safe access in and out of the water. The intended life of simple pleasures turns rapidly into an elusive vision defying hopes, wishes and dreams, and crushing, both metaphorically and literally, those in vain quest of the pastoral ideal. Thus, Titus, the son of Charles's childhood sweetheart, Hartley, drowns when trying to merge with nature. It is as if the forces of nature as well as the house, decided to refuse to obey the interloper through a series of failures, disasters, diseases, nightmarish visions and mysterious appearances and disappearances. Charles thus fails to get a single refreshing night's sleep in the house, or write into his memoir/diary/philosophical journal, he is subject to the vision of a sea-monster, he repeatedly falls ill and he achieves peace only after he acknowledges the unattainability of his pastoral plan, leaves the place and embraces city life in London.

Besides their great vitality and their ability to subjugate the countryside, speeding through it in their motor-cars, buying country houses and land, some members of the Wilcox clan do not identify with, and are not even willing to comprehend, their mother's passion for their country house, Howards End: "She approached [...] trailing noiselessly over the lawn, and there was actually a wisp of hay in her hands. She seemed to belong not to the young people and their motor, but to the house, and to the tree that overshadowed it" (Forster, HE 19). Ironically, though Ruth Wilcox takes immense pleasure from the wisp of hay she smells repeatedly, the rest of her family suffer from hay fever and are unable to leave the house or even open the window. All members of the Wilcox family, apart from Mrs Wilcox, stake their claim in the future, whereas everything their mother embodies - wisdom, aristocracy, tradition, superstition, "dwelling" in the sense underlined by Martin Heidegger, is rooted in the past and thus stands in their way. The Wilcoxes are willing to build the future of the nation and trample on traditions, but, despite their immense vitality, cockiness and brute force, they are defeated by a wisp of hay, unable even to go bathing without strenuous preparations:

If Margaret wanted to jump from the motor-car, she jumped; if Tibby thought paddling would benefit his ankles, he paddled; if a clerk desired adventure, he took a walk in the dark. But these athletes seemed paralysed. They could not bathe without their appliances, though the morning sun was calling and the last mists were rising from the dimpling stream. Had they found the life of the body after all? (Forster, HE 186)

The Wilcoxes take hold of the country and its future, symbolising economic progress, ruthlessness and power, which attracts the liberal minds of the Schlegel sisters with an unexpected and seemingly inexplicable allure: "To be all day with them in the open air, to sleep at night under their roof, had seemed the supreme joy of life, and had led to that abandonment of personality that is possible prelude to love" (Forster, HE 20). This enchantment, however, fades away with the growing evidence of their inability to "connect" both in the physical as well as the metaphysical sense. Neither Charles Arrowby, nor the Wilcoxes are able to achieve any kind of authentic experience, which both novels emphasise through their absolute inability to commune with nature. Although Henry Wilcox makes an effort and decides to reside in Howards End, the inability remains unchanged, with him trapped inside and the rest of the clan at a safe distance from the house and all its connotations. Charles, on the other hand, ironically approximates authenticity when he 
abandons his far-fetched, theatrical efforts to achieve it. The realm he belongs to is the city, where he finds a peace protected against the unconstrained forces of nature and hordes of his friends, and the whimsical, malevolent nature of Shruff End, his house by the sea.

\section{1 "You shall see the connection if it kills you, Henry!"}

The way in which Ruth Wilcox, Margaret and Helen Schlegel deal with possession, and houses in particular, is diametrically different from that of the Wilcoxes: "'You see,' continued Helen to her cousin, 'Wilcoxes collect houses as your Victor collects tadpoles"'( Forster, $H E$ 145). Whereas they see houses purely as investments, Ruth, Margaret and Helen identify them as means of connection, sometimes even as sanctuaries. Howards End is thus elevated to a shrine to England, capable of linking some of its inhabitants with the English land and past. Houses in Howards End are undoubtedly laden with various symbolic properties. However, there is one which overshadows the rest, and that is the symbol of the feminine. Although men may hold the keys, the doors of the houses truly open, in the metaphorical sense of the word, to women only. Those who threaten to invade are crushed - Charles is imprisoned, Henry is broken and Leonard Bast killed. The Schlegels' attempts at connection, which might be summarised by Margaret's marriage and Helen's son, required a considerable number of sacrifices, heroic effort and at times the employment of the brute force of the Schlegels, as illustrated by Margaret's utterance "You shall see the connection if it kills you, Henry!" (Forster, $H E$ 263). Nevertheless, the novel concludes with a seemingly pastoral image of the two sisters sitting on the lawn overlooking the meadows.

The final acquisition of Howards End by the Schlegels, Henry's eventual submission, Helen's son, the beauty of the pastoral, the number of meadows dividing them from the red rust of civilization, all these elements point to the victory of the Schlegel sisters. The nature of such a victory, achieved by means of exclusion, submission and the occasional annihilation of human beings, highlights the highly complex, knotty character of Forster's vision of human relationships.

Both The Sea, The Sea and Howards End question the demands of the metaphorical as well as the literal view, besides tackling the subjects of unrequited love, unfulfilled desires, twisted, dysfunctional relationships and doomed love stories. Both the reader and the characters are led to believe that what they witness is the Schlegels' good-hearted struggle for universal connection and the emotional turmoil of Charles who is fighting for his long-lost love, Hartley. Nevertheless, each emotional movement presented in the novels can be interpreted as delicate and yet rather ostentatious manipulation and what seems to be a full-blooded passion may be revealed as cold-blooded scheming.

Charles projects his desire for a lost world of purity and innocence into the resurrection of his childhood love for Hartley: "My love for Hartley was nearly an end in itself. Twist and turn as she might, whatever happened she could not escape me now" (Murdoch 462) who, in the spirit of the Gothic, he captures, secludes and unsuccessfully tries to trick into submission. Charles's new life with Hartley would, he hopes, continue in the same idealistic vein as his life by the sea, which, since the beginning of his efforts, repeatedly proves to be the opposite of what he yearned for. Before walking out on him, Hartley was supposed to have become the instrument through which Charles could achieve ultimate peace and quiet in his artificial paradise: "And we would gently cherish each other and there would be a vast plain goodness and a sort of space and quiet, unspoilt and uncorrupted. And I would join the ordinary people and be an ordinary person, and rest[...]" (Murdoch 398).

Charles, however, does not seek a truthful, loving relationship, but continues in the arrogant spirit of the Schlegel sisters who attempt to connect heroically with the rest of the world despite the wishes or well-being of others: "[...] and there was an intelligence in her quiet negative reception of the kiss which was itself a communication" (Murdoch 229). In the case of Charles, no children are conceived, on the contrary, human life is sacrificed when Titus, Hartley's adoptive son, drowns in the sea, close to Shruff End. Similarly, the Schlegel sisters' attempts at connection cause the death of Leonard Bast who is literally crushed and buried by a pile of books symbolising the knowledge and wisdom he did not seem worthy to embrace and the sphere to which he would not have been able to belong.

\section{Heidegger's Hut}

Martin Heidegger's lecture "Building Dwelling Thinking”, which he delivered in 1951 in front of an audience of architects, builders and engineers in war-torn Germany, has become a seminal text of contemporary architecture, inspiring both architectural theory and practice. Its emphasis on the humanist dimension of architecture is noted in works by Karsten Harries, Juhani Pallasmaa, Steven Holl, Rowan Moore, Adam Sharr, Alain de Botton and Christopher Day. In all his texts concerning the topics of building and dwelling, Heidegger employs the example of a Black Forest farmhouse, which he presents as a shining example of the ancient form of dwelling, of staying in place. While praising its rootedness and the way it enhances a sense of belonging, he calls attention to its role within the process of learning how to dwell, which requires a continual effort rather than being easily achievable.

"Building Dwelling Thinking”, “...Poetically man dwells...” and other of Heidegger's writings on this topic were inspired by, if not directly written in, a hut situated in the Black Forest mountains where he spent a considerable amount of time writing and studying. Although it seemed unlikely to provide Heidegger and his family members with sufficient comfort, he absolutely insisted on minimal furnishings. Each simple item of its sparse equipment was charged with philosophical potential and was able to approximate him to the essential elements of existence. Heidegger often stressed its vital role in his philosophy, and yet he never moved there and lived a relatively ordinary city life in a town house as the chair in philosophy at Freiburg University. In his monograph, Heidegger's Hut, Adam Sharr, an influential theoretician and successful practicing architect, claims that Heidegger's house in the city was actually modelled on the 
hut and that the windows of Heidegger's study faced the Black Forest mountains and a valley, so he had at least an unobstructed view of his treasured places. The town house as such did not suit the philosopher since all its comforts and the emphasis put on family life was "clouding rather than emphasizing questions of being" (Sharr 103). What is more, Heidegger never mentioned the house in his writings, which is in notable contrast to his passionate embrace of the solitary existence in the mountains and his vocal, repeatedly expressed admiration for his hut with its strong philosophical resonance.

The hut and the house symbolize two opposing tendencies that considerably influenced Heidegger's life and creation: "provincialism" and "cosmopolitanism":

These positions are often considered in opposition. Cosmopolitans dismiss the provincial as invidious: introvert, inbred, prone to exclusion, and reliant upon romantic myth. Provincials dismiss the cosmopolitan as deluded: bound to abstract systems and priorities, entranced by fickleness of fashion, setting itself and its self-appointed heroes on false pedestals. (Sharr 107)

In order to understand his position within this opposition, it is necessary to interpret rightly his metaphorical texts: Heidegger does not urge his listeners or readers to literally live in the past, adopting outdated ways of living, such as farming, nor does he impose any kind of social restrictions or the exclusion of fellow human beings. His conception of dwelling is not restricted to place, the past or to social status, it resides in the ability to search for the centre and to find it repeatedly, always fresh and new: "The real dwelling plight lies in this, that mortals ever search anew for the nature of dwelling, that they must ever learn to dwell" (Heidegger 159). Karsten Harries, one of the most influential contemporary architectural theoreticians, emphasises the importance of the ethical aspect of architecture. His understanding of dwelling, therefore, is in tune with Heidegger's conception, as it underlines its humble, respectful and assiduous nature: "To be genuinely at home in this world, we have to affirm our essential homelessness, a homelessness illuminated by shifting ideas of genuine dwelling, figures of home, and precarious conjectures about what it might mean to dwell near the centre" (Harries 200).

In Howards End, Margaret Schelgel learns an identical lesson concerning the nature of dwelling. She and Helen are cast away from the centre, only to search for it with greater vigour: "The loss of Wickham Place had taught her more than its possession." (Forster, HE 189). If Forster's novel portrays volatility as the main principle of dwelling, the lesson is repeated in The Sea, the Sea where Murdoch's approach to authentic existence coincides with Heidegger's conception of dwelling. Both novels might be consequently viewed as depictions of a quest for dwelling or a truthful, authentic existence. Although both "quests" relate partially to the exclusive social standing of the protagonists, their significance should not be diminished by any kind of material conditioning, including their social or spatial exclusivity. A similar approach applies to Heidegger's hut, a place which permeates his writing. Although it was an exceptional place whose position in the landscape enabled a complete and self-imposed seclusion, and was also furnished according to Heidegger's demands for a Spartan simplicity, it should be understood in terms of opening new horizons and possibilities rather than as being the manifestation of a middle-class eccentricity: "Arguably, the greatest potential of the hut lies in the hope that such centring power need not be invidious or exclusive" (Sharr 112). Its close connection with the philosopher's existence: "The small building was the philosopher's datum, its particularities delineating the particularities of his life and work" (Sharr 112), its ability to communicate philosophical dimensions of existence, its capacity to shelter and at the same time expose a human being, all these exceptional qualities transformed it into a powerful source of inspiration for the philosopher and also for generations of architects who tried to replicate its beneficial, inspiring effects. In spite of the fact that it is typically the life in the countryside that is romanticised and therefore associated with authenticity of existence and philosophical significance, the true challenge for architects, dwellers as well as the authors of literary depictions, is to achieve such "centering" regardless of the relative social standing of all those involved or of the urban setting of their work.

\section{Conclusion: In Search of a House with a View}

"The house was insignificant, but the prospects from it would be an eternal joy" (Forster, HE 185).

Howards End and The Sea, The Sea revolve around two middle-class country houses, one being an ancient, converted farmhouse and the other an ordinary seaside villa. The relation between the place and its inhabitants, as it is presented on the example of Howards End and Shruff End, challenges the stereotypical depiction of a country house situated in a seemingly idyllic, rural setting. The actual portrayals reveal a wide range of implications of such a type of often idealised living arrangement in connection with class as well as the extreme, people-exclusive interpretation of environmental preoccupation.

Though the houses are still depicted as being essential to the process of establishing, shaping and constructing the authentic existence of their inhabitants, it is, nevertheless, the desire for a view, both literal and metaphorical, which determines the narrative and the nature dwelling presented in both novels. The frequency of the view from or of the house considerably exceeds the presentation of the inside of the houses. The depiction of the house from the outside, quite an unexpected angle for its inhabitant, who you would expect inside, is especially prominent in The Sea, The Sea, where Charles spends the majority of his peaceful nights sleeping on the rocks rather than returning to the stifling atmosphere of Shruff End. "After a while, I came back towards Shruff End. It seemed to be unusually illuminated and looked like a doll's house" (Murdoch 389). This perspective emphasises the theatrical preoccupation of Charles as he continues in his life-long carer of a famed director and stages his retreat. But it echoes, in its own, twisted way, his 
major undertaking to become a real, authentic, good human being. Ironically, it is the house and the sea, which should have represented his new mindset, which expel him so that he realises that what he wants to achieve cannot be rehearsed and performed in the secluded environment of Shruff End, but that it requires a life-long commitment and endeavour. What is more, it is not the countryside, but the city that is his natural habitat.

Howards End opens and closes with the view from the house, into the garden and the meadow. Although the red rust of civilization will likely find its way there and invade the Schlegel's sanctuary in the future, for the time being the Wilcoxes are defeated and the meadow is mown: "Tom's father was cutting the big meadow. He passed again and again amid whirring blades and sweet odours of grass, encompassing with narrowing circles the sacred centre of the field" (Forster, HE 286). Margaret and Helen, the two heroic connectors, are looking into a future marked solely by seasonal change and domestic demands such as frozen pipes or a gale blowing down the wych-elm, with Helen thinking about "these little events becoming part of her, year after year" (Forster, HE 286). Merging gradually with the house and its surroundings, it is their turn to encompass, with narrowing circles, the sacred centre of existence and thus to dwell.

The view presented in The Sea, The Sea and Howards End is never devoid of interruptions and obstacles: there are wild elements, lost wills, inquisitive visitors and a number of misconceptions, failed efforts and faulty judgements on the side of the main protagonists. The bourgeois, class-exclusive pastoral, which would omit all these inappropriate intrusions, is abandoned and replaced by, if highly ironical and far-reaching at times, meditation upon the nature of genuine dwelling.

\section{References}

Bachelard, Gaston. The Poetics of Space. [1958] Boston: Beacon Press, 1994. Print.

Bowen, Elizabeth. The Hotel. [1927] Harmondsworth: Penguin Books, 1943. Print.

---. The Last September. [1929] London: Penguin Books, 1943. Print.

---. The House in Paris. [1935] New York : Knopf, 1936. Print.

---. Bowen Court \&Seven Winters. London: Vintage Books, 1999. Print.

Bradbury, Malcolm. The Modern British Novel. London: Penguin Books, 1994. Print.

Chalupský, Petr. The Postmodern City of Dreadful Night. The Image of the City in the Works of Martin Amis and Ian McEwan. Saarbrücken: VDM Verlag Dr. Müller, 2009. Print.

Day, Elizabeth. "Elizabeth Jane Howard: 'I'm 90. Writing is what gets me up in the morning." The Observer. 7 April 2013. Web. 29 July 2013.

DeLillo, Don. The Body Artist. [2001]London: Picador, 2011. Print.

Dimbleby, David. How We Built Britain. London: Bloomsbury Publishing, 2007. Print.

Ford, Maddox Ford. Parade's End. [1928] London: Campbell, 1992. Print.

Forster, Edward Morgan. A Room with a View. [1908] London: Penguin Books, 2000. Print.

---. Howards End. [1910] London: Penguin Books, 2000. Print.

---. Two Cheers for Democracy. [1951] London: Penguin Books, 1965. Print.

Foucault, Michel. "Of Other Spaces.” [1967] In Diacritics. Vol. 16, No.1, 1986. 22-27. Print.

Fowles, John. The Collector. [1963] London: Vintage, 2004. Print.

Franková, Milada. Human Relationships in the Novels of Iris Murdoch. Brno: Masarykova univerzita, 1995. Print.

Girouard, Mark. A Country House Companion. New Haven: Yale University Press, 1987. Print.

Harries, Karsten. The Ethical Function of Architecture. Cambridge: The Massachusetts Institute of Technology Press, 1997. Print.

Heidegger, Martin. (2001): Poetry, Language, Thought. New York: Perennial Classics, 2001. Print.

Howard, Elizabeth Jane. The Light Years. [1990] London: Pan Books, 1991. Print.

Lucas, John. "The Sunlight on the Garden." Seeing Double, Revisioning Edwardian and Modernist Literature. Ed. C.M. Kaplan A.B. Simpson, London: Macmilan Press, 1996. 59-75. Print.

Mandler, Peter. The Fall and Rise of the Stately Home. New Haven \& London: Yale University Press, 1997. Print.

McEwan, Ian. Amsterdam. [1998] London: Vintage Books, 1999. Print.

Monbiot, George. "I love nature. For this I am called bourgeois, romantic - even fascist." The Guardian. 8 July 2013. Web. 16 July 2013.

Murdoch, I. The Sea, The Sea. [1978] London: Vintage, 1999. Print.

Poole, Steven. "Is our love of nature writing bourgeois escapism?” The Guardian. 6 July 2013. Web. 16 July 2013.

---. "I belong in a field.” Stevenpoole.net. 6 July 2013. Web. 11 October 2014.

Robbins, Martin. "Class and the Countryside.” The Guardian. 9 July 2013. Web. 21 July 2013.

Sackville-West, Vita. All Passion Spent. [1931] London: Virago Press, 1986. Print.

Sharr, Adam. Heidegger's Hut. Cambridge, Massachusetts: Massachusetts Institute of Technology Press, 2006. Print.

Spurr, David. Architecture and Modern Literature. Ann Arbor: The University of Michigan Press, 2012. 
Stone, Wilfred. "Howards End: Red-bloods and Mollycoddles." The Cave and the Mountain, A Study of E.M. Foster. Stanford: Stanford University Press, 1966. 234-275. Print.

---. "Forster, the Environmentalist". Seeing Double, Revisioning Edwardian and Modernist Literature. Ed. C.M. Kaplan A.B. Simpson, London: Macmilan Press, 1996. 174-192. Print.

Topolovská, Tereza. "Days of Peculiar Splendour: Howards End and The Sea, The Sea in the Context of Summer House Fiction." English Language and Literature Studies. Toronto: Canadian Center of Science and Education.Vol.5, Issue 3, 2015, 1-12. Print.

Weldon, Fay. “Weekend.” Teachingenglish.org. Teaching English, 2013. Web. 12 Aug. 2013.

Williams, Raymond. (1993). The Country and the City. [1973] London: The Hogarth Press, 1993. Print.

Woolf, Virginia. Orlando: A Biography. [1928] London: Penguin Books, 2006. Print.

---. A Haunted House: The Complete Shorter Fiction. London: Vintage Books, 2003. Print.

---. A Room of One's Own. [1929] London: Penguin Books, 2000.

\section{Notes}

Note 1. "Houses have their own ways of dying, falling as variously as the generations of men, some with a tragic roar, some quietly but to an afterlife in the city of ghosts, while from others - and thus was the death of Wickham Place the spirit slips before the body perishes. It had decayed in the spring, disintegrating the girls more than they knew, and causing either to accost unfamiliar regions. By September it was a corpse, void of emotion, and scarcely hallowed by the memories of thirty years of happiness" (Forster, HE 219).

Note 2. See Virginia Woolf's "A Haunted House" in Selected Short Stories [1921]; Orlando: A Biography [1928], Elizabeth Bowen's The Hotel [1927]; The Last September [1929]; The House in Paris [1935]; Bowen Court [1946] or Vita Sackville-West's All Passion Spent [1931].

Note 3. For a detailed study of this phenomenon see Topolovská, Tereza. "Days of Peculiar Splendour: Howards End and The Sea, The Sea in the Context of Summer House Fiction." English Language and Literature Studies. Toronto: Canadian Center of Science and Education.Vol.5, Issue 3, 2015, 1-12. Print.

Note 4. He did so most explicitly in A Room with a View or Howards End, and later in his 1951 collection of essays, Two Cheers for Democracy.

Note 5. Seen from the highly ambiguous Modernist point of view, the city is on the one hand "celebrated as a cosmopolitan intellectual and cultural centre" and on the other hand condemned as "symbol of an overall spiritual and cultural decay, the ultimate manifestation of the impasse in which modern civilization found itself trapped"(Chalupský $15)$.

Note 6. Forster, along with D.H. Lawrence, is the last great English novelist who tried to include all social classes in his work. Beside this, they both believed that the violation of aesthetic values committed by industrialisation might be the explanation of what was wrong in the society: "The real tragedy of England," writes Lawrence, "is the tragedy of ugliness. The country is so lovely: the man-made England is so vile" (as quoted in Stone "Howards End: Red-bloods and Mollycoddles." 175). Forster agrees, but he does not agree easily, for he saw that beauty (conditioned by the presence of space) to be only another special privilege.

Note 7. In Heidegger's Hut, the study of the influence of the simple, authentic, efficient hut situated in the Black Forest Mountains on Heidegger's philosophy and writing, its author, Adam Sharr, hints at the possibility of Heidegger's identification with the hut being "the indulgence of bourgeois romance" (Sharr 111)

Note 8. Monbiot's riposte lies, quite predictably, in identifying a love of nature with a love of art. He calls attention to capitalist-infused corporate thinking which defies the right of the natural world to exist. Seen from Monbiot's perspective, Poole and those like him are marked as "philistines" for seeing no value in the wonders which enrapture others.

Note 9. Similarly, the house presented in the first instalment of the Cazalet chronicles, The Light Years, published in 1990 and written by Elizabeth Jane Howard shelters three generations of the Cazalets during two romantic, interwar summers in Sussex. The never-ending process of adding to the former farmhouse, together with the absence of proper planning, contribute to the lack of practicality, comfort and sustainability of the resulting house, "a rambling muddle built round a hall with a staircase that led to an open gallery from which the bedrooms could be reached" (Howard 67). As in the case of Fay Weldon's "Weekend", a family spirit should have been induced by their concentration in one place. However, the maintenance of the household and preparation of lavish meals place high demands on those in charge and their experience is a far cry from the romantic, idealized, relaxing time they are supposed to be having there.

After decades of moderate professional success, life in the shadows cast by her husbands and relatively tumultuous private life, the work of Elizabeth Jane Howard, who died at the beginning of 2014, is finally attracting the degree of attention it deserves, with Hilary Mantel and Martin Amis (her stepson from her marriage to Kingsley Amis) emphasising the quality of her works. Amis, her stepson, called her 'the most interesting woman writer of her generation' alongside Iris Murdoch". As Elizabeth Day noted in the article published in the Guardian, Howard herself "is mildly astonished by the resurgence of interest in her work. Any talk of how her reputation as a writer is undergoing a long overdue re-evaluation is greeted with a startled glare" (Day "Elizabeth Jane Howard: 'I'm 90. Writing is what gets me up in the morning.") 